\title{
SOFT CHEESE AND GRILLED CHICKEN AS A POSSIBLE SOURCE OF HUMAN SALMONELLOSIS WITH SPECIAL ATTENTION TO HUMAN RISK FACTORS
}

\author{
ALSHIMAA A. HASSANIEN ${ }^{1}$ and EMAN M. SHAKER ${ }^{2}$ \\ ${ }^{1}$ Departement of Zoonoses, Faculty of Veterinary Medicine, Sohag University, Egypt. \\ ${ }^{2}$ Departement of Food Hygiene, Faculty of Veterinary Medicine, Sohag University, Egypt.
}

Received: 31 December 2016; Accepted: 22 January 2017

\begin{abstract}
This work was designed to detect the presence of Salmonella species among patients with food poisoning manifestations in three central hospitals located in three cities (Sohag, Tema and Elmaragha) in Sohag Governorate and from foods consumed by the majority of patients as soft cheese and grilled chicken using microbiological, PCR method (using 16S rRNA specific primer for Salmonella species) and serological typing of Salmonella species, as well as risk factors related to Salmonella infection in human was identified based on data collected from the patients. The results illustrated that Salmonella species was detected in 9 (4.6\%), 2 $(2.2 \%)$ and $5(4.2 \%)$ of the examined patients, soft cheese and grilled chicken respectively. Salmonella Typhimurium was the predominant serotype followed by $S$. Infantis, S. Enteritidis and S. Kentucky. Owing to the risk factors associated with infection; patients in age group ranged from15-25, males and peoples in contact with infected persons and animals were more susceptible to the infection. Public health education, rapid detection of infection, risk factors identification and collaboration between health and agriculture authorities are important to set a successful control strategy.
\end{abstract}

Key words: Salmonella species, Soft cheese, Grilled chicken, Risk factors, PCR

\section{INTRODUCTION}

Infection with Salmonella species is considered the most common food borne contaminant and recognized globally in developed and developing countries causing high morbidity and economic losses (Ammari et al., 2009). The clinical manifestations include fever, watery diarrhea, nausea, abdominal pain, headache and occasional constipation with hospitalization required in severe cases of infection (Joseph and Carlos, 2012). Identification of infection risk factors associated with human infection (animal contact, type of food consumed by patients as dairy products made from raw milk or raw meat, contact with infected persons and history of chronic diseases) will assist the health authorities to set a control strategy (Lapo et al., 2014). Although some studies reported that direct contact with infected animals is the main risk factor for salmonellosis, the foodborne route is still regarded as the primary transmission route (Kevin et al., 2012) through consumption of contaminated foods mainly those of animal origin (Hernandez et al., 2005) such as milk, egg, beef and poultry meat (Alcaine et al., 2007). The major

Corresponding author: Dr. ALSHIMAA A. HASSANIEN

E-mail address: Hassanien2008@yahoo.com

Present address: Departement of Zoonoses, Faculty of Veterinary Medicine, Sohag University, Egypt. pathogenic serovars of Salmonella which infect human from food of animal origin include $S$. Enteritidis , S. Typhimurium, S. Heidelberg (Jawale and Lee, 2012), S. Infantis and S. Kentucky (Wafaa et al., 2012), this brought attention for sensitive and rapid detection assay of Salmonella species in food. Culture and biochemical methods are inexpensive but require at least three days for the negative result and five to seven days for positive result confirmation, in addition, the power of biochemical test affected by the environmental contamination (Jasson et al., 2010), so it is important to reduce the detection time by applying molecular methods such as PCR by using 16S ribosomal RNA (16S rRNA) primer to detect and discriminate between Salmonella and non Salmonella species (Ziemer, and Steadham, 2003). This study focused on the presence of Salmonella species among food poisoning patients and in some food products consumed by the majority of patients as soft cheese and grilled chicken sold in three cities in Sohag Governorate and explore the factors associated with human infection with salmonellosis.

\section{MATERIALS AND METHODS}

\section{1- Study design and data collection}

The study was performed from August 2015 to Septemper 2016 in three central hospitals located in three cities (Soahg, Tema and Elmaragha) in Sohag Governorate. The population under study comprised 
195 patients with manifestations like food poisoning admitted to the three hospitals and from food consumed by the majority of patients such as soft cheese (90) and grilled chicken (120). Data was collected from patients using a form available at http://www.bccdc.ca/health-professionals/ professional-resources/surveillance-forms with modifications including personal information, animal contact and contact with infected persons.

\section{Collection and preparation of samples}

\section{a- Human samples}

195 stool samples were collected from patients in sterile cups and sent immediately to the laboratory in the Faculty of Veterinary Medicine, Sohag University.

\section{b- Food samples}

Food samples were collected based on the data obtained from patients according to the type of food consumed by the majority of patients and if possible from the same seller. We cannot examine the same food consumed by all patients because they eat all food and no leftovers were found and several patients lives in villages far from the central hospital in addition; some patients can't remember which food caused their illness. Therefore, food samples was purchased from restaurants, cafeterias, grocery and market vendors in the three cities under study (Sohag,Tema and Elmaragha) including 90 soft cheese ( 30 from each city) and 120 grilled chicken samples ( 40 from each city). The collected samples were sent to the Food hygiene department laboratory in the Faculty of Veterinary Medicine, Sohag University and prepared for microbiological examination according to (APHA, 1992).

\section{2- Bacteriological examination of samples (ISO 6579, 2002)}

Stool and food samples were preenriched in buffered peptone water for 24 hours at $37^{\circ} \mathrm{C}$, then $1 \mathrm{ml}$ was transferred to Rappaport Vassiliadis broth (BD, Germany) for selective enrichment and incubated at $42^{\circ} \mathrm{C}$ for 24 hours. A loopful from each incubated tube was streaked on Xylose-lysine desoxycholate agar (Himedia, India) and incubated at $37^{\circ} \mathrm{C}$ for 24 hours. The distinct colonies were streaked onto nutrient agar (Condalab) slants for identification by several biochemical tests as triple sugar iron (TSI), Indole, Methyl red, Simmon citrate and Urease.

\section{3- Molecular identification of Salmonella species} QIAamp DNA mini kit, QIAGEN, Germany was used for DNA extraction from the suspected isolates. PCR was used for the detection of $16 \mathrm{~S}$ rRNA gene specific for Salmonella species as recorded by Ziemer and Steadham (2003) with cycling condition including step of initial denaturation for $5 \mathrm{~min}$ at $94^{\circ} \mathrm{C}, 35$ cycles of denaturation at $94^{\circ} \mathrm{C}$ for $1 \mathrm{~min}$, annealing for $1 \mathrm{~min}$ at $55^{\circ} \mathrm{C}$, extension for $7 \mathrm{~min}$ at $72^{\circ} \mathrm{C}$ using thermal cycler (Bio-Rad, USA). Electrophoresis was performed for PCR product by staining $1.5 \%$ agarose gel with ethidium bromide then photographed under transilluminator UV light (Biometra). A 100 pb DNA ladder (Norgen biotek, Canada) was used as a DNA marker. The primer sequence is F: TGT TGT GGT TAA TAA CCG CA and R: CAC AAA TCC ATC TCT GGA with product size $574 \mathrm{pb}$.

\section{4- Serological identification of Salmonella species} Serological identification of Salmonella strains was performed in central laboratories of microbiology of Ministry of Health, Egypt based on flagellar $(\mathrm{H})$ and somatic (O) antigens according to (Popoff et al., 2004).

\section{RESULTS}

Table 1: Bacteriological identification of Salmonella species in human and food samples.

\begin{tabular}{|c|c|c|c|c|c|c|c|c|c|}
\hline \multirow{3}{*}{ City } & \multicolumn{3}{|c|}{ Human samples } & \multicolumn{3}{|c|}{ Soft cheese } & \multicolumn{3}{|c|}{ Grilled chicken } \\
\hline & \multirow{2}{*}{$\begin{array}{c}\text { No. of } \\
\text { patients }\end{array}$} & \multicolumn{2}{|c|}{ Salmonella sp. } & \multirow{2}{*}{$\begin{array}{c}\text { No. of } \\
\text { samples }\end{array}$} & \multicolumn{2}{|c|}{ Salmonella sp. } & \multirow{2}{*}{$\begin{array}{c}\text { No. of } \\
\text { samples }\end{array}$} & \multicolumn{2}{|c|}{ Salmonella sp } \\
\hline & & No & $\%$ & & No & $\%$ & & No & $\%$ \\
\hline Sohag & 58 & 2 & 3.4 & 30 & 1 & 3.3 & 40 & 1 & 2.5 \\
\hline Tema & 71 & 4 & 5.6 & 30 & 1 & 3.3 & 40 & 3 & 7.5 \\
\hline Elmaragha & 66 & 3 & 4.5 & 30 & 0 & 0 & 40 & 2 & 5 \\
\hline Total & 195 & 9 & 4.6 & 90 & 2 & 2.2 & 120 & 6 & 5 \\
\hline
\end{tabular}


Table 2: PCR and serelogical identification of Salmonella species in human samples.

\begin{tabular}{|c|c|c|c|c|c|c|c|c|c|}
\hline \multirow{3}{*}{ Locality } & \multirow{3}{*}{$\begin{array}{c}\text { No. of } \\
\text { patients }\end{array}$} & \multirow{2}{*}{\multicolumn{2}{|c|}{$\begin{array}{c}\text { Positive } \\
\text { 16S rRNA gene }\end{array}$}} & \multicolumn{6}{|c|}{ Serological identification } \\
\hline & & & & \multicolumn{2}{|c|}{ S.Typhimurium } & \multicolumn{2}{|c|}{ S. Infantis } & \multicolumn{2}{|c|}{ S. Enteritidies } \\
\hline & & No & $\%$ & No & $\%$ & No & $\%$ & No & $\%$ \\
\hline Sohag & 58 & 2 & 3.4 & 1 & 1.7 & 1 & 1.7 & 0 & 0 \\
\hline Tema & 71 & 4 & 5.6 & 2 & 2.8 & 1 & 1.4 & 1 & 1.4 \\
\hline Elmaragha & 66 & 3 & 4.5 & 3 & 3.4 & 0 & 0 & 0 & 0 \\
\hline Total & 195 & 9 & 4.6 & 6 & 3.1 & 2 & 1.02 & 1 & 0.5 \\
\hline
\end{tabular}

Table 3: Patient characteristics and risk factors related to Salmonella species infection.

\begin{tabular}{lllll}
\hline & $\begin{array}{c}\text { Food poisoning patients } \\
\text { N/195 }\end{array}$ & $\begin{array}{c}\text { Salmonella species } \\
\text { N/9 }\end{array}$ \\
\hline 1- Personal information & No & $\%$ & No & $\%$ \\
\hline a- Age & & & & \\
\hline $15-25$ & 48 & 24.6 & 4 & 44.4 \\
\hline $26-35$ & 63 & 32.3 & 2 & 22.2 \\
\hline $36-45$ & 50 & 25.6 & 1 & 11.1 \\
\hline $46-55$ & 16 & 8.2 & 0 & 0 \\
\hline$>55$ & 18 & 9.2 & 2 & 22.2 \\
\hline b- Gender & & & & 6 \\
\hline Male & 133 & 68.2 & 6 & 66.7 \\
\hline Female & 62 & 31.7 & 3 & 33.3 \\
\hline 2- Animal contact & 102 & 52.3 & 5 & 55.5 \\
\hline a- At home & & & & \\
\hline Chicken & 31 & 30.4 & 0 & 0 \\
\hline Cattle and chicken & 34 & 33.3 & 1 & 11.1 \\
\hline b- At work & & & & 11 \\
\hline Poultry seller & 13 & 12.7 & 1 & 11.1 \\
\hline Poultry farm worker & 15 & 14.7 & 1 & 11.1 \\
\hline Food handler & 4 & 3.9 & 1 & 11.1 \\
\hline d- Both at home and work & 9 & 8.8 & 1 & 11.1 \\
\hline 3- Contact with infected persons & 93 & 47.7 & 4 & 44.4 \\
\hline
\end{tabular}

Table 4: PCR and serelogical identification of Salmonella species in food samples.

\begin{tabular}{|c|c|c|c|c|c|c|c|c|c|}
\hline \multirow{3}{*}{ Type of food } & \multirow{3}{*}{$\begin{array}{l}\text { No. of the } \\
\text { examined } \\
\text { samples }\end{array}$} & \multirow{2}{*}{\multicolumn{2}{|c|}{$\begin{array}{c}\text { Positive } \\
\text { 16S rRNA } \\
\text { gene }\end{array}$}} & \multicolumn{6}{|c|}{ Serological identification } \\
\hline & & & & \multicolumn{2}{|c|}{ S.Typhimurium } & \multicolumn{2}{|c|}{ S. Infantis } & \multicolumn{2}{|c|}{ S. Kentucky } \\
\hline & & No & $\%$ & No & $\%$ & No & $\%$ & No & $\%$ \\
\hline Soft cheese & 90 & 2 & 2.2 & 1 & 1.1 & 1 & 1.1 & 0 & 0 \\
\hline Grilled chicken & 120 & 5 & 4.2 & 2 & 1.7 & 2 & 1.7 & 1 & 0.8 \\
\hline Total & 210 & 7 & 3.3 & 3 & 1.4 & 3 & 1.4 & 1 & 0.5 \\
\hline
\end{tabular}


Table 5: Frequency distribution of Salmonella species in soft cheese in three cities in Sohag Governorate.

\begin{tabular}{|c|c|c|c|c|c|c|c|c|c|}
\hline \multirow{3}{*}{ City } & \multirow{3}{*}{$\begin{array}{l}\text { No. of the } \\
\text { examined } \\
\text { samples }\end{array}$} & \multicolumn{8}{|c|}{ Soft cheese } \\
\hline & & \multicolumn{2}{|c|}{ S.Typhimurium } & \multicolumn{2}{|c|}{ S. Infantis } & \multicolumn{2}{|c|}{ S. Kentucky } & \multicolumn{2}{|c|}{ Total } \\
\hline & & No & $\%$ & No & $\%$ & No & $\%$ & No & $\%$ \\
\hline Sohag & 30 & 0 & 0 & 1 & 33.3 & 0 & 0 & 1 & 33.3 \\
\hline Tema & 30 & 1 & 33.3 & 0 & 0 & 0 & 0 & 1 & 3.3 \\
\hline Elmaragha & 30 & 0 & 0 & 0 & 0 & 0 & 0 & 0 & 0 \\
\hline
\end{tabular}

Table 6: Frequency distribution of Salmonella species in grilled chicken in three cities in Sohag Governorate.

\begin{tabular}{|c|c|c|c|c|c|c|c|c|c|}
\hline \multirow{3}{*}{ City } & \multirow{3}{*}{$\begin{array}{l}\text { No. of the } \\
\text { examined } \\
\text { samples }\end{array}$} & \multicolumn{8}{|c|}{ Grilled chicken } \\
\hline & & \multicolumn{2}{|c|}{ S.Typhimurium } & \multicolumn{2}{|c|}{ S. Infantis } & \multicolumn{2}{|c|}{ S. Kentucky } & \multicolumn{2}{|c|}{ Total } \\
\hline & & No & $\%$ & No & $\%$ & No & $\%$ & No & $\%$ \\
\hline Sohag & 40 & 1 & 2.5 & 0 & 0 & 0 & 0 & 1 & 2.5 \\
\hline Tema & 40 & 1 & 2.5 & 1 & 2.5 & 0 & 0 & 2 & 5 \\
\hline Elmaragha & 40 & 0 & 0 & 1 & 2.5 & 1 & 2.5 & 2 & 5 \\
\hline
\end{tabular}

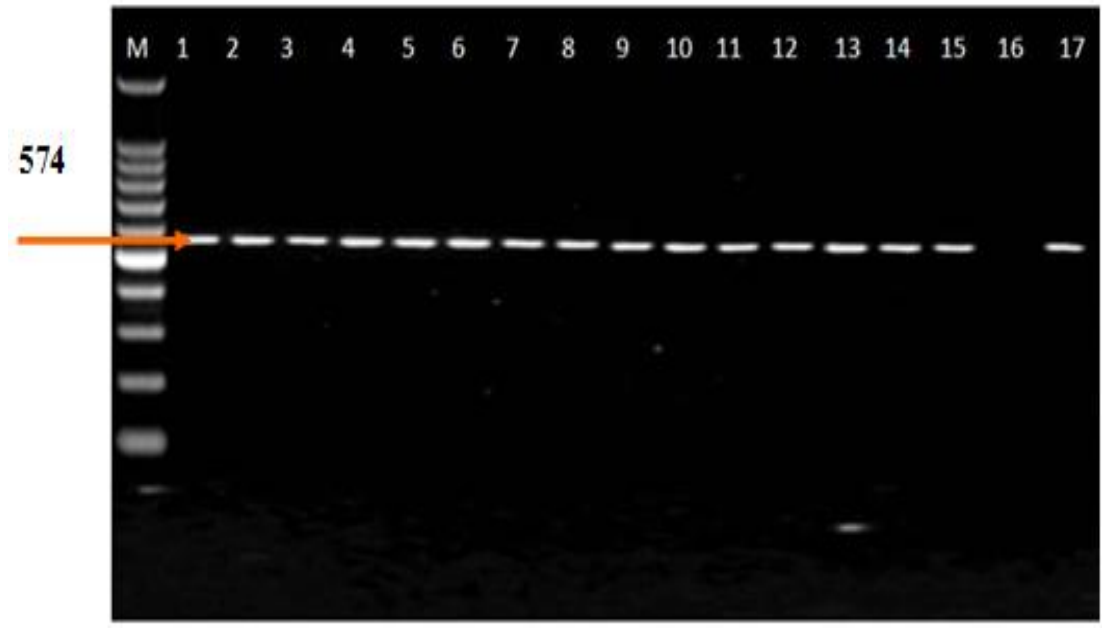

Figure 1: PCR result of 16S rRNA gene specific for Salmonella species in human and food samples. Lane M: 100 bp ladder, lane $1,2,3,4,5,6,7,8,9,10,11,12,13,14,15$ and 17: positive 16S rRNA gene, lane 16: Negative $16 \mathrm{~S}$ rRNA gene.

\section{DISCUSSION}

Salmonella species were detected by the microbiological methods in $9(4.6 \%)$ out of 195 patients suffering from food poisoning manifestation admitted to three central hospitals in Sohag Governorate, $2(2.2 \%)$ of 90 soft cheese and $6(5 \%)$ of 120 grilled chicken samples purchased from groceries, restaurants, cafeterias and market vendors in the three cities under study (Sohag, Tema and Elmaragha) (Table 1). Although bacteriological methods are inexpensive, it is consuming time, so early detection of Salmonella species in human and food is important for human health and food industry (Aida et al., 2012). Therefore rapid and sensitive PCR method was used for confirmation of the obtained bacteriological strains using Salmonella species specific 16S rRNA primers and found that human and soft cheese samples give the same results obtained by culture methods while in grilled chicken samples, only one sample was negative by PCR (Table 2,4 and Figure 1). In comparison between PCR and conventional microbiological methods, PCR is more successful especially in Salmonella outbreaks because it is rapid and requires limited manpower (Van der et al., 2000).

The results shown in Table 2 revealed that among 195 patients suffering from food poisoning manifestation, $9(4.6 \%)$ were positive for Salmonella species, this results goes parallel with Gharieb et al. (2015) and Hassan et al. (2016). Higher results were obtained by 
Nader et al. (2015) and lower results were reported by Mayada and Adel (2015), this diversity may be related to the geographical distribution, seasonal variation, food habits and the hygienic practice taken during food handling, transportation, and contact with animals and infected patients. According to the regional distribution; Tema reported the highest infection rate $4(5.6 \%)$ followed by Elmarahga 3 $(4.5 \%)$ and Sohag $2(3.4 \%)$, this may be clarified by the lack of personal hygiene, bad eating habits and unrestricted control measures taken by the authorities for food safety and health inspection in this locality.

Salmonella serotyping is important in the epidemiological investigation of Salmonella infection; identifying Salmonella serotype is helpful in providing the information about the source and the severity of infection (Molbak et al., 2006). As reported by Thomas et al. (2012); the most prominent Salmonella serovar is Salmonella Typhimurium which detected in $6(3.1 \%)$ patients and Salmonella Infantis was detected in two $(1.02 \%)$ patients while only one (0.5\%) patient represent Salmonella Enteritidis opposite to Ammar et al. (2010) who detected Salmonella Enteriridis as a predominant serovar. Salmonella Infantis has previously been found in chicken eggs, poultry, cattle and animal feed but human infections has been increased around the world, also it considered one of the main Salmonella serotypes causing human gastroenteritis (Najjar et al., 2012).

Table 3 illustrated the patient characteristics and risk factors related to Salmonella species infection among nine salmonellosis patients, the results revealed that the highest infection rate $4(44.4 \%)$ was detected in the age group from15-25 years while the older age 46-55 gave negative results for Salmonella species, and infection in males $6(66.7 \%)$ was higher than females $3(33.3 \%)$, this may be due to that people in this age (15-25) and males spend most of their time outside homes and buy their meals from restaurants, markets and grocery which may lack the hygienic measures. Exposure to animals either occupational or at home increase the probability of Salmonella species infection as $5(55.5 \%)$ patients were found to be in contact with animals. As shown in our results; two patients $(22.2 \%)$ out of nine patients having a history of contact with infected persons were harbored Salmonella species in their stool, therefore detection of Salmonella species is important for diagnosis of infected patients and identification of carriers, hence; contact with infected patients with gastrointestinal manifestations especially inside the household considered a risk factor and source of infection among the family member (Lapo et al., 2014).

Cheese is the most ready to eat milk product consumed by the Egyptian people and widely distributed in groceries and vendors in local markets without any observations from the health authorities. It is manufactured by traditional methods on small scale in farmer houses under unhygienic measures using raw milk or milk heated below the pasteurization temperature with high microbial load (Robinson and Tamime, 2002). So it is considered a risk food and consumption of this cheese leading to Salmonella outbreaks and other pathogens such as Staphylococcus aureus and Listeria monocytogens (Hall and French, 2011).

Contamination of foods especially grilled chicken depends on the level of Salmonella on poultry meat used as a raw product beside storage temperature and cross contamination at retail during slaughtering, scalding, evisceration and distribution. Also incomplete heat treatment during preparation and unhygienic practice during handling and preparation (El-Leithy and Rashad, 1989).

The results in Table 4 revealed that two (2.2\%) out of 90 soft cheese and 5 (4.2\%) out of 120 grilled chicken samples were positive for Salmonella species, the obtained results is similar to those obtained by Arif (2012) and Effimia (2015) and lower than that reported by Mayada and Maha (2014), and opposite to Ortolani et al. (2010) who cannot detect Salmonella species in soft cheese. The presence of Salmonella species in food may be resulted from that food not freshly prepared and left for long time at room temperature which enhances the multiplication of bacteria. Regarding to Salmonella serotypes, Salmonella Typhimurium, Salmonella Infantis and Salmonella Kentucky was detected in food samples with percentages of $1.4,1.4$ and 0.5 , respectively. The occurrence of the same Salmonella species in human stool proved that the contaminated food is a major source of salmonellosis infection (Hernandez, 2005) and the detection of Salmonella Enteritidis in human stool and their absence in the examined food samples explained by presence of other source of infection such as contact with animals or infected persons or other type of food.

Results in Table 5 and 6 explained that grilled chicken considered as a possible source of Salmonella species infection in the three examined localities, while soft cheese was detected only in two clusters, their absence in Elmaragha does not preclude the possibility of its existence with illegal distribution and marketing in poor hygienic measures (Molla et al., 2003). Therefore, education of the public about the food safety is required parallel with restricted control measures taken by the health and veterinary authorities.

\section{CONCLUSION}

Salmonellosis is transmitted to human through several pathways including food and non food sources, risk factor identification will reflect the 
epidemiological picture which is not clear in Egypt and help the health and veterinary authorities to set a control strategy to reduce the infection.

\section{ACKNOWLEDGMENT}

Authors would like to thank the medical staff in hospitals under the study for their help in samples collection.

\section{REFERENCES}

Aida, J.; Seyed, D.; Alireza, H. (2012): Simple and rapid detection of Salmonella $s p$. from cattle feces using polymerase chain reaction (PCR) in Iran. African J. of Microbiology Research Vol. 6(24): 5210-5214.

Alcaine, S.; Warnick, L. and Wiedmann, M. (2007): Antimicrobial resistance in nontyphoidal Salmonella. J. Food Prot., 70: 780-790.

American Public Health Association (APHA) (1992): Compendium of methods for the microbiological examination of foods, Washington, Wash, USA, $3^{\text {rd }}$ edition.

Ammar, A.; Ahmed, A.; Asawy, A. and Ibrahim, A. (2010): Bacteriological studies on Salmonella Entertidis isolated from different sources in Dakhlia governorat. Assiut Vet. Med. J., 56(124): 125-135.

Ammari, S.; Laglaoui, A.; En-nanei, L. (2009): Isolation, drug resistance and molecular characterization of Salmonella isolates in northern Morocco. J. of Infect. Develop. Countries, 3: 41-49.

Arif, E. (2012): Isolation and identification of Salmonella species from local cheeses in Sulaimani province. Al-Anbar J. Vet. Sci., 5 (1): 82-84.

Effimia, E. (2015): Prevalence of Listeria monocytogenes and Salmonella spp. in ready to eat foods in Kefalonia, Greece. J. Bacteriol Parasitol, 6 (5): 243.

El-Leithy, M. and Rashad, F. (1989): Bacteriological studies on ground meat and its products. Archiv für Lebensmittelhygiene, 40: 58-61.

Gharieb, R.; Tartor, Y. and Khedr, M. (2015): Nontyphoidal Salmonella in poultry meat and diarrhoeic patients: prevalence, antibiogram, virulotyping, molecular detection and sequencing of class I integrons in multidrug resistant strains. Gut Pathog, 7: 34-44.

Hall, W. and French, N. (2011): An assessment of available information on raw milk cheeses and human disease. Ministry of Agriculture and Forestry. Technical Paper No: 2011/58.

Hassan, A.; Hala, S. and Gihan, K. (2016): Serological identification and antimicrobial resistance of Salmonella isolates from broiler carcasses and human stools in Beni-Suef,
Egypt, Beni-suef University journal of basic and applied sciences, 5: 202-207.

Hernandez, T.; Sierra, A.; Rodriguez-Alvarez, $C$. (2005): Salmonella enterica serotypes isolated from imported frozen chicken meat in Canary Islands. J. Food Prot., 68, 12: 2702-2706.

ISO 6579 (2002): Microbiology of food and animal feeding stuffs: Horizontal method for the detection of Salmonella spp.

Jasson, V.; Jacxsens, L.; Luning, P.; Rajkovic, A. and Uyttendaele, M. (2010): Alternative microbial methods: an overview and selection criteria. Food Microbiology, 27(6): 710-730.

Jawale, C. and Lee, J. (2012): Antimicrobial resistance of Salmonella isolated from food animals. Food research international, 45: $819 \mathrm{e} 830$.

Joseph, A. and Carlos, G. (2012): Salmonella detection methods for food and food ingredients, Available from: http://www. intechopen.com/books/salmonella-a-dangerous -foodborne-pathogen/salmonella-detectionmethods-for-food-and-food-ingredients.

Kevin, J.; Lorin, D. and Margare, T.A. (2012): Farm animal contact as a risk factor for transmission of bovine associated Salmonella subtypes. Emerging Infectious Diseases, 18(12).

Lapo, G.; Remko, E.; Ingrid, F.; Max, H.; Yvonne, D. and Wilfrid, $P$. (2014): Risk factors for human Salmonellosis originating from pigs, cattle, broiler chickens and egg laying hens: A combined case-control and source attribution analysis, PLoS ONE, 9(2): e87933.

Mayada, G. and Adel, E. (2015): Prevalence and characterization of antibiotic resistance food borne pathogens isolated from locally produced chicken raw meat and their handlers. J. Dairy Vet. Anim. Res., 2(6): 00062.

Mayada, G. and Maha, A. (2014): Culture versus PCR for Salmonella Species identification in some dairy products and dairy handlers with special concern to its zoonotic importance. Veterinary Medicine International.

Molbak, K.; Olsen, J. and Wegener, H. (2006): Salmonella infections, p. 55-115. In H. Reimann, D. C. (eds.), Foodborne infections and intoxications. Academic Press.

Molla, B.; Alemayehu, D. and Salah, W. (2003): Sources and distribution of Salmonella serotypes isolated from food animals, slaughterhouse personnel and retail meat products in Ethiopia: 1997-2002. Ethiopian Journal of Health Development, 17: 63-70.

Nader, M.; Rasheed, M. and Hiba, H. (2015): Molecular identification of Salmonella Typhimurium from chicken, meat, and human by PCR, Int'l Conf. on medical genetics, cellular and molecular biology, pharmaceutical and food sciences (GCMBPF-2015) June 5-6, 
2015 Istanbul. Avilable at: http://dx.doi.org/ 10.15242/IICBE.C0615050.

Najjar, Z.; Furlong, C.; Stephens, N. (2012): An outbreak of Salmonella Infantis gastroenteritis in a residential age care facility associated with thickened fluids. Epidemiol Infect, 140: 2264-72.

Ortolani, M.; Anderson, K.; Paula, M.; Gabriela, N. and Lul's Augusto, N. (2010): Microbiological quality and safety of raw milk and soft cheese and detection of autochthonous lactic acid bacteria with antagonistic activity against Listeria monocytogenes, Salmonella Spp., and Staphylococcus aureus. Foodborne pathogens and disease, 7(2): 175-180.

Popoff, M.; Bockemuh, J. and Gheesling, L. (2004): Supplement 2002 (No. 46) to the KauffmannWhite scheme. Res Microbiol, 155: 568-70.

Robinson, $R$. and Tamime, A. (2002): Maintaining a clean working environment. In: Robinson, R.K. (Ed.), Dairy microbiology handbook, the microbiology of milk and milk products, $3^{\text {rd }}$ ed. Wiley, New York: 561-591.

Thomas, J.; Slawson, R. and Taylor, W. (2012): Salmonella serotype diversity and seasonality in urban and rural streams. J. of Applied Microbiology, 114: 907-922.

Van der, Z.; Huis, I. and Veld. J. (2000): Methods for the rapid detection of Salmonella. In Salmonella in domestic animals: 373-391. Edited by Wray, C. and Wray, A. Wallingford, UK: CABI Publishing.

Wafaa, A.; Soumaya, S. and Hatem, M. (2012): A survey on Salmonella species isolated from chicken flocks in Egypt. Asian J. of animal and veterinary advances, 7(6): 489-501.

Ziemer, C. and Steadham, S. (2003): Evaluation of the specificity of Salmonella PCR primers using various intestinal bacterial species. Letters in Applied Microbiology, 37: 463-469.

\section{الجبن الطرى والفراخ المشوية كمصدر محتمل لعدوى السالمونيلا فى الانسان مع الاهتمام بعوامل الخطورة

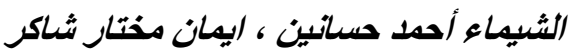

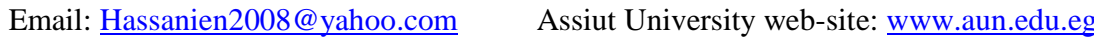

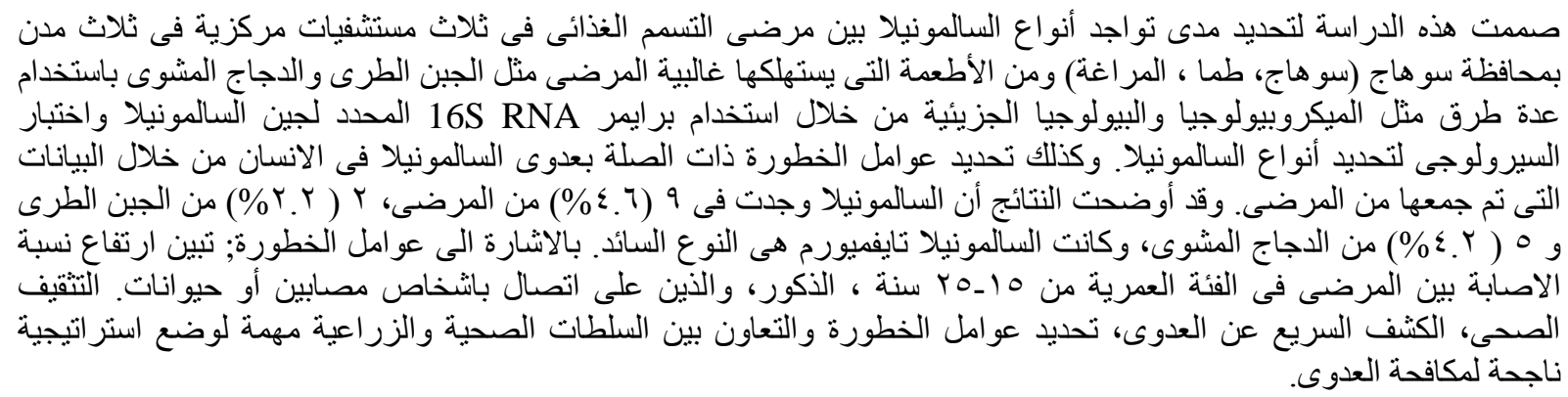

